\title{
Integrated Disease Management of Storage Rot of Ginger (Zingiber officinale) caused by Fusarium sp. in Himachal Pradesh, India
}

\author{
Sushma Sharma ${ }^{1}$, Netra Prakash Dohroo ${ }^{2}$, Shanmugam Veerubommu ${ }^{3}$, \\ Sumitra Phurailatpam ${ }^{2}$, Neelam Thakur ${ }^{4}$ and Ajar Nath Yadav ${ }^{5^{*}}$ \\ ${ }^{1}$ Department of Agriculture, Akal College of Agriculture, Eternal University, Baru Sahib, \\ Sirmour, India \\ ${ }^{2}$ Department of Plant Pathology, Dr. Y. S. Parmar \\ University of Horticulture and Forestry, Solan, India \\ ${ }^{3}$ Division of Plant Pathology, Indian Agricultural Research Institute, New Delhi, India \\ ${ }^{4}$ Department of Zoology, Akal College of Basic Sciences, \\ Eternal University, Baru Sahib, Sirmour, India \\ ${ }^{5}$ Microbial Biotechnology Laboratory, Department of Biotechnology, Akal College of \\ Agriculture, Eternal University, Baru Sahib, Sirmour, India \\ *Corresponding author
}

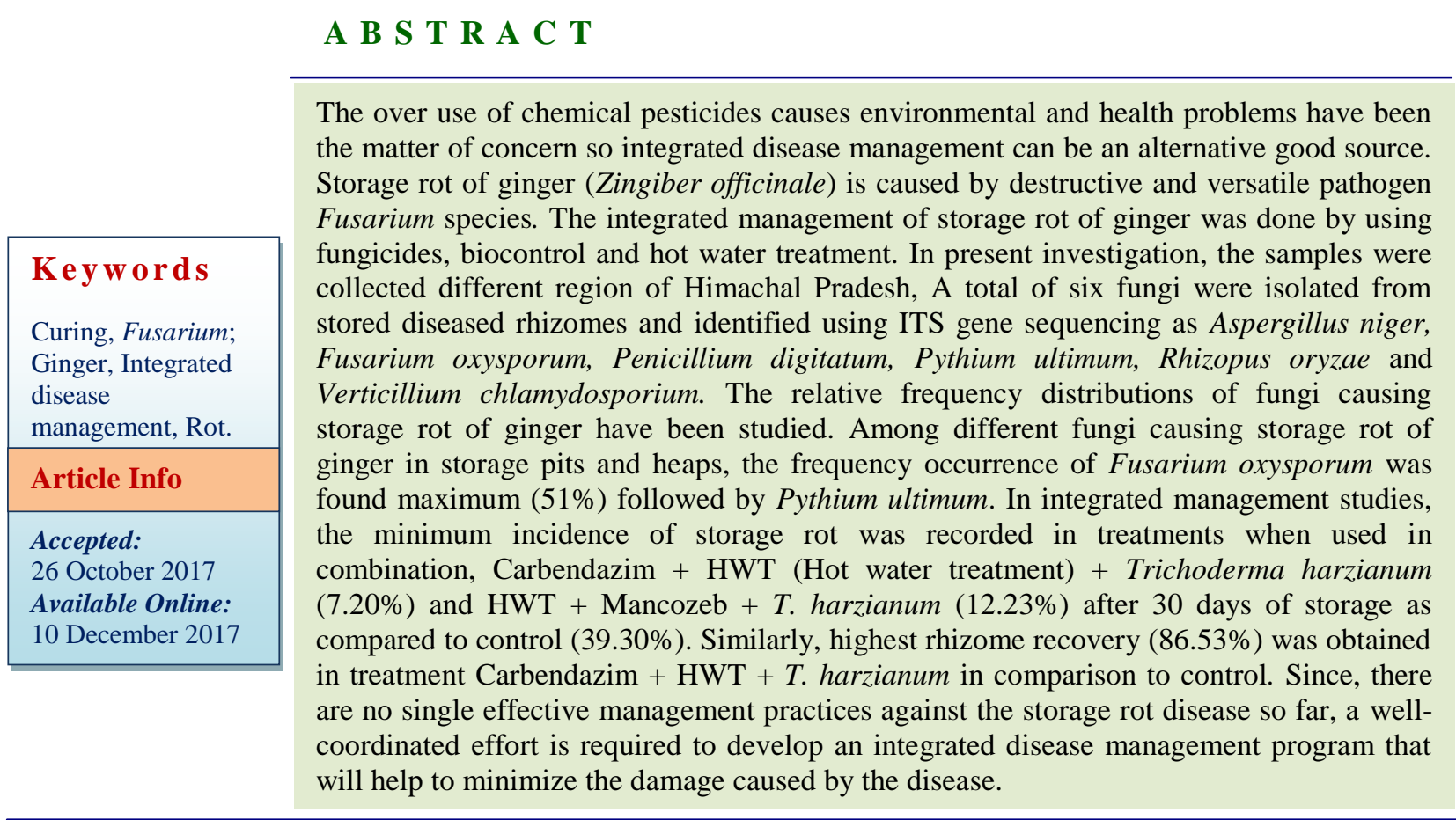

\section{Introduction}

Ginger (Zingiber officinale) is an important cash crop of Himachal Pradesh fetching remunerative returns to the growers. At present, ginger is utilized as herbal remedy 
against various conditions, including arthritis, rheumatism, sprains, muscular aches, pains, sore throats, cramps, constipation, indigestion, vomiting, hypertension, dementia, fever and infectious diseases (Ernst and Pittler 2000; Shukla and Singh 2007; Grzanna et al., 2005). Research over the last decade has shown that ginger has the potential to be used in the prevention and treatment of a myriad of diseases through modulation of biological activities (Rahmani 2014). The main pharmacological actions of ginger phytochemicals include immunomodulatory, antitumorigenic, anti-inflammatory, antiapoptotic, antihyperglycaemic, antilipidemic and antifungal activities (Kim et al., 2005; Hsiang et al., 2013).

India is a leading producer of ginger in the world. The ginger is an important cash crop of mid and low hill areas covering an area of 3,495 hectare with annual production of 50,034 metric tones in Himachal Pradesh (Indian Horticulture Database, 2012). It is intensively cultivated in districts of Bilaspur, Hamirpur, Kangra, Mandi, Shimla, Sirmour, Solan and Una in Himachal Pradesh. Sirmour district alone contributes highest productivity and is having $3 / 4^{\text {th }}$ of the area and production of the state. It is one of the most important cash crops for farmers. However, during in the last few years, the ginger crop was damaged by different diseases in field, storage and market.

Post-harvest losses in ginger is a serious concern as after putting hard labour for 7-8 months in production, the precious harvest is lost due to negligence in crop production and storage in underground pits and open heaps at various stages. The post-harvest losses are affected by various biotic and abiotic causes. During storage, the rhizomes soft was affected by fungal infection (50\%) within 3 to 4 weeks. It have been reported that, storage rot of ginger was caused by Pythium sp.,
Fusarium oxysporum f. sp. zingiberi and Sclerotium rolfsii but the frequency occurrence of Fusarium oxysporum was maximum (50\%) among fungi causing storage rot of ginger in storage pits and heaps. Though, a number of fungal pathogens have been reported to be associated with the disease from time to time (Mitra and Subramaniam 1928), but the species of Pythium and Fusarium are of common occurrence causing heavy damage to the crop.

Management of post-harvest diseases is a tedious task in ginger as use of chemicals results in accumulation of residues on the ginger. The residue of chemicals on the surface of ginger results in adverse effects on the health of consumers (Tripathi et al., 2008). However, extensive use of chemicals as antifungal agents might lead to severe side effects such as carcinogenicity, terotogenecity and other genotoxic properties (Basilico and Basilico 1999). Further, uncontrolled use of such chemicals leads to biohazordous effects on ecosystem and lead to resistance in pathogens against these fungicides (Brent and Hollomon 1995). Thus alternative approaches should be preferred for management of postharvest diseases in ginger and it should be eco-friendly for environments and human.

The generally the microbial inoculants are eco-friendly application to inhibits growth to different groups of fungi causing serious problems in different crops (Verma et al., 2014; 2015a; b; 2016b; 2017; Suman et al., 2016). The present investigation is focus to use the integrated disease management of storage rot of ginger.

The present exploration was carried out to record the incidence of storage rot in major ginger growing areas of Himachal Pradesh and integration of fungicides and biological control practices against storage rot pathogen to evaluate their impact on disease and growth parameters. 


\section{Materials and Methods}

\section{Sampling sites}

Survey was conducted in mid hills (Pits) in the month of April and in low hills (Heaps) during the month of May, 2014 in Himachal Pradesh to record incidence of storage rot and extent of loss in storage. The areas surveyed included: Charna, Shillai, Sangrah, Tikkar, Sohal, Dungi, Rajgarh, Timbi, Thor Niwar, Ghandoori and Harlu in district Sirmour; Ghanahatti, Shoghi, Panesh, Chamba Panesh, Ladevi Panesh, Chanog in Shimla district; Nauni, Kandaghat, Arki, Kunihar, Kasauli, Oachghat and kalaghat in Solan district; Namhol, kandraur, Ghumarwin, Chandpur, Chlehli and Panoh in district Bilaspur. The incidence of the disease was recorded as following:

Number of diseased rhizomes Disease incidence $(\%)=$

Total number of rhizomes

The incidence of storage rot in ginger was recorded on the basis of \% rhizomes infected. The diseased specimens collected either from pits or heaps were carried to laboratory in alkathene and paper bags. The diseased samples of ginger were properly labeled for date of collection, method of storage and location.

\section{Isolation and characterization of fungi}

Isolation of fungi has been done according to the method described by Rawlins (1933). The fungi were isolated from the affected rhizomes on potato dextrose agar (PDA) medium under aseptic conditions. In case of isolation for external fungi, the affected rhizomes were washed with tap water in order to remove adhering soil. Small bits (2 to 3 $\mathrm{mm}$ ) of diseased tissues were cut from the borders of the diseased and healthy tissues with the help of a sterilized scalpel. The bits were surface sterilized by dipping in $1 \%$ sodium hypochloride solution for $15 \mathrm{sec}$ and then washed thoroughly 2-3 times with sterilized distilled water. The bits were transferred to potato dextrose agar medium, under aseptic conditions. The inoculated test tubes and petri plates were incubated at $25 \pm 1^{\circ} \mathrm{C}$ for fungal growth. The fungal growth thus obtained was further purified by hyphal tip method on PDA in slants and petriplates.

Morphological studies have been done for isolated fungi i.e. mycelia, sporangia and oospores in case of Pythium ultimum, size and shape of mycelium, microconidia and macroconidia, presence or absence of sporodochia in Fusarium oxysporum, mycelial characters, phialides and spores etc. in Verticillium chlamydosporium were recorded. The measurements were taken with the help of ocular micrometer. The data were recorded on various characters of these fungi and values tabulated.

For the molecular characterization, the genomic DNA was extracted and the amount of DNA extracted was electrophoresed on $0.8 \%$ agarose gel using methods describes earlier by Verma et al., (2016a). PCR amplification of ITS gene and sequencing has been done as method described by Yadav et al., (2016a). The partial ITS gene sequences of the isolated strains were compared with those available in the databases. Identification at the species level was determined using a ITS gene sequence similarity of $\geq 97 \%$ with that of a prototype strain sequence in the GenBank (Yadav et al., 2016b; Yadav et al., 2017). The phylogenetic tree was constructed on the aligned datasets using the Maximum Likehood method implemented in the program MEGA 4.0.2. The partial ITS gene sequences were submitted to NCBI GenBank and accession numbers assigned as $\mathrm{KJ}$ 847732 and KJ 847734-42. 


\section{Evaluation of integrated disease management for ginger rots}

To study the effect of curing rhizomes were dried in shade for curing at different periods viz., $0,12,24,36$ and 40 hour to remove the excessive moisture in the ginger. Each treatment was replicated three times. The rhizomes were stored in the pits at vegetable farm of University after curing. The rhizomes were taken out from the pits at the planting time in the month of April, 2014. The \% losses in weight and disease incidence were recorded. The $\%$ loss in weight was recorded as following:

Loss in weight $(\%)=($ Rhizome weight before storage - Rhizome weight after storage / Rhizome weight before storage) $\times 100$

The integrated disease management study was carried out during $2014-15$ by integrating best rhizome treatments obtained during earlier studies on physical, chemical, botanical and antagonist methods of evaluation. Different treatments used in integrated approach were Carbendazim $(0.2 \%)$, Propineb $(0.3 \%)$, Mancozeb (0.3\%), Neemazal (4\%), $T$. harzianum $(0.5 \%), T$. viride $(0.5 \%)$, Cow urine $(5 \%)$ and hot water treatment at $50{ }^{\circ} \mathrm{C}$ for $10 \mathrm{~min}$. Different treatments were first dissolved in small quantity of water and then mixed in the desired quantity of water to make final volume 5 litres in each case. The healthy rhizomes ( $3 \mathrm{~kg}$ per treatment) were weighed and then dipped for 60 minutes in the prepared suspension.

The treated rhizomes were dried in shade for $24 \mathrm{~h}$ to remove excess of moisture from their surface. A separate control was also maintained in which all operations were carried out in the same manner except the treatment. Each treatment was replicated three times. The rhizomes were stored in pits during 2014-15 in first week of December at vegetable farm of the University. The rhizomes were taken out from the pits before the planting time in the month of June, 2015. The data were recorded on $\%$ disease incidence, healthy rhizome recovery, sprouting, shriveling, bud length and bud colour. The presence (+) or absence (-) of mould was also recorded. The surface shriveling and sprouting status was recorded by visual observation as - (none, 0\%), + (slight, < 30\%), ++ (moderate, 30-70\%) and +++ (severe, 70-100\%) (Dohroo 1995).

\section{Results and Discussion}

Major growing areas of ginger in Himachal Pradesh are Sirmour, Shimla, Solan and Bilaspur. The survey and sampling has been done during the month of May, 2014 to record incidence of storage rot of ginger under pits and heaps. It is evident from the data Table 1 that the maximum incidence $(47.0 \%)$ under heaps and (25.0\%) under pits at Rajgarh locality of Sirmour district followed by Kasauli $(17.0 \%)$ under pits and $(21.0 \%)$ in heaps of Solan district. In Shimla district, maximum incidence $(17.0 \%)$ was observed in Ghanahatti under pits and minimum incidence was in Chanog (3.2\%) under heaps conditions of storage.

The maximum incidence of storage rot in Bilaspur district was recorded in Namhol (14.0\%) in pits and minimum in Panoh (3.0\%) under heaps condition. During the year 1991, the survey report of different ginger growing areas in four districts of Himachal Pradesh i.e., Sirmour, Solan, Shimla and Bilaspur revealed that maximum disease incidence of $87 \%$ in Solan. Earlier, Dohroo (1993) also reported 50\% losses in storage by rhizome rot of ginger caused by $F$. oxysporum f. sp. zingiberi. Ravindran and Babu (2005), observed infestation of ginger in store to an extent of $4.0-22.5 \%$, when stored for 4-6 months. Two seasonal surveys were carried 
out in March/April and June/July, 2009 to identify fungi associated with stored ginger in Nigeria. The results showed high frequency of Aspergillus flavus, A. niger, Fusarium oxysporum and Rhizopus sp. in the dried ginger samples with A. flavus having maximum predominance.

Fungi were isolated from diseased rhizomes and their frequency distribution was studied. It is clear from the data (Fig. 1) that frequency occurrence of Fusarium oxysporum was maximum (51\%) among fungi causing storage rot of ginger in storage pits and heaps. It was followed by Pythium ultimum (19.0\%) and Verticillium chlamydosporium (12\%).

The minimum frequency distribution was recorded in case of Rhizopus oryzae (3.0\%) followed by Aspergillus niger (8.0\%) and Penicillium digitatum (7.0\%). Sharma and Jain (1977) observed that out of 29 fungi associated with ginger externally or internally, four fungi viz., Fusarium oxysporum, Pythium deliense, P. myriotylum and Pseudopapulaspora kendrickii were present internally in rhizomes and were responsible for deterioration of the rhizomes in storage. The frequency of $F$. oxysporum was however, maximum in ginger rhizomes as compared to others.

Ram and Thakur (2010), reported association of Alternaria alternata, Aspergillus niger, Fusarium solani, Macrophomina phaseolina, Pythium aphanidermatum, Rhizoctonia solani and Rhizopus stolonifer under traditional storage structures of ginger rhizomes. Out of these, $P$. aphanidermatum and $F$. solani were found in more frequency of association with storage rot of ginger. In morphological studies, three different fungi were subcultured from stock culture on freshly prepared potato dextrose agar (PDA) medium and were incubated at $25 \pm 1{ }^{\circ} \mathrm{C}$. The morphological characters of the fungi were studied in fresh culture (7 days old). Various characters i.e. diameter of hyphae, micro and macroconidia, septation of conidia, phialides, sporangia, oospores of the isolated fungi were recorded and are presented in Table 2.

\section{Fusarium oxysporum Schlecht}

The colonies of the fungus were floccose with mycelia and pinnotal type of linear growth. The hyphae were 2.1-4.2 $\mu \mathrm{m}$ and branched. Microconidia were oval to fusiform, aseptate and measured $4.2-6.3 \times 2.4 \mu \mathrm{m}$. Chlamydospores were smooth to rough walled and both intercalary and terminal on short lateral branches in mycelium. Peach yellow to bluish pigmentation was found to be produced by the fungus in medium.

The fungus were identified as $\mathrm{FUO}(1)$ as Fusarium equiseti; $\mathrm{FUO}(\mathrm{B}), \quad \mathrm{FUO}(\mathrm{G})$, $\mathrm{FUO}(11), \mathrm{FUO}(3), \mathrm{FUO}(8)$ and $\mathrm{FUO}(\mathrm{M})$ as Fusarium oxysporum; FUO(10) as Fusarium proliferatum and $\mathrm{FUO}(\mathrm{A}), \mathrm{FUO}(\mathrm{f})$ as Fusarium sp. ITS gene sequencing and phylogenetic analysis of selected fungus show that all the isolates having >97 to $100 \%$ similarity with the sequences within the GenBank. The phylogenetic tree of identified species of fungi was constructed to determine their affiliations (Fig. 2).

Effect of curing on storage rot of ginger was studied and it was evident from the data Table 3 that minimum loss in weight $(3.50 \%)$ occurred when rhizomes were given curing for 0 hours followed by 12 hours $(8.37 \%), 24$ hours $(12.55 \%)$ and 36 hours $(21.55 \%)$. The maximum loss in weight $(28.50 \%)$ was recorded in curing at 40 hour. The minimum incidence of 7.86 and $19.49 \%$ was observed at 40 and 36 hours of curing and were statistically at par with each other. It was followed by $24(26.55 \%)$ and 12 hours (37.45\%) of curing. The later two treatments were statistically at par with each other. 
Table.1 Incidence of storage rot of ginger in Himachal Pradesh during 2014-15

\begin{tabular}{|c|c|c|}
\hline District/Village & Pits & Heaps \\
\hline \multicolumn{3}{|l|}{ Sirmour } \\
\hline 1. Sangrah & 12.0 & 15.0 \\
\hline 2. Tikkar & 7.0 & 4.0 \\
\hline 3. Sohal & 5.0 & 3.0 \\
\hline 4. Dungi & 8.0 & 3.0 \\
\hline 5. Timbi & 5.0 & 6.0 \\
\hline 6. Rajgarh & 25.0 & 47.0 \\
\hline 7. Ghandoori & 7.0 & 5.0 \\
\hline 8. Shillai & 5.0 & 5.0 \\
\hline 9. Harlu & 10.0 & 11.0 \\
\hline 10. Charna & 17.0 & 12.0 \\
\hline \multicolumn{3}{|l|}{ Shimla } \\
\hline 11. Ghanahatti & 17.0 & 8.0 \\
\hline 12. Shoghi & 7.0 & 14.0 \\
\hline 13. Panesh & 10.0 & 13.0 \\
\hline $\begin{array}{l}\text { 14. Chamba } \\
\text { Panesh }\end{array}$ & 6.0 & 7.0 \\
\hline 15. Ladevi Panesh & 4.0 & 6.5 \\
\hline 16. Chanog & 5.0 & 3.2 \\
\hline \multicolumn{3}{|l|}{ Solan } \\
\hline 17. Nauni & 5.0 & 12.0 \\
\hline 18. Kasauli & 17.0 & 21.0 \\
\hline 19. Kalaghat & 15.0 & 8.0 \\
\hline 20. Oachghat & 6.0 & 11.0 \\
\hline 21. Arki & 7.0 & 9.0 \\
\hline 22. Kunihar & 8.0 & 10.0 \\
\hline 23. Kandaghat & 10.0 & 8.0 \\
\hline \multicolumn{3}{|l|}{ Bilaspur } \\
\hline 24. Namhol & 14.0 & 9.0 \\
\hline 25. Kandraur & 3.0 & 15.0 \\
\hline 26. Ghumarwin & 6.0 & 12.0 \\
\hline 27. Chandpur & 8.0 & 6.0 \\
\hline 28. Chlehli & 4.0 & 7.0 \\
\hline 29. Panoh & 7.0 & 3.0 \\
\hline
\end{tabular}

Table.2 Morphological characteristics of fungi associated with storage rot of ginger

\begin{tabular}{lcccccc}
\hline Fungi & \multicolumn{5}{c}{ Morphological characters } \\
\cline { 2 - 7 } & $\begin{array}{c}\text { Hyphae } \\
(\mu \mathrm{m})\end{array}$ & $\begin{array}{c}\text { Microconidi } \\
\mathrm{a}(\mu \mathrm{m})\end{array}$ & $\begin{array}{c}\text { Macroconidia } \\
(\mu \mathrm{m})\end{array}$ & $\begin{array}{c}\text { No. of } \\
\text { Septa }\end{array}$ & $\begin{array}{c}\text { Linear } \\
\text { growth }\end{array}$ & Pigmentation \\
\hline $\begin{array}{l}\text { Fusarium } \\
\text { oxysporum Schlecht }\end{array}$ & $2.1-4.2$ & $4.2-6.3 \times 2.4$ & $10-27 \times 2-4$ & $1-4$ & $\begin{array}{c}\text { Pinnota } \\
1 \text { type }\end{array}$ & $\begin{array}{c}\text { Peach yellow } \\
\text { to bluish }\end{array}$ \\
\hline
\end{tabular}


Int.J.Curr.Microbiol.App.Sci (2017) 6(12): 3580-3592

Table.3 Effect of curing of rhizomes on disease incidence and weight loss

\begin{tabular}{cccc}
\hline $\begin{array}{c}\text { Curing duration } \\
(\mathbf{h r s})\end{array}$ & Loss in weight & Disease incidence & Mean \\
\hline 0 & $3.50(12.94)$ & $41.57(40.15)$ & $41.0(39.83)$ \\
12 & $8.37(17.27)$ & $37.45(37.73)$ & $33.0(35.01)$ \\
24 & $12.55(22.30)$ & $26.55(31.02)$ & $24.05(29.34)$ \\
36 & $21.55(27.66)$ & $19.49(26.19)$ & $16.93(24.23)$ \\
40 & $28.50(39.52)$ & $7.86(16.27)$ & $8.08(19.10)$ \\
$\mathrm{CD}_{(0.05)}$ & 0.81 & 0.51 & \\
\hline
\end{tabular}

Table.4 Effect of integration of different rhizome treatments against storage rot of ginger

\begin{tabular}{|c|c|c|c|c|c|}
\hline \multirow[t]{2}{*}{ Treatment } & \multicolumn{4}{|c|}{$\begin{array}{c}\text { Incidence }(\%) \text { of storage rot at } \\
\text { different intervals (days) }\end{array}$} & \multirow[t]{2}{*}{ Mean } \\
\hline & 30 & 60 & 90 & 120 & \\
\hline $\begin{array}{l}\text { Bavistin }(0.2 \%)+T \\
\text { harzianum }(0.5 \%)+\text { Cow } \\
\text { urine }(5 \%)\end{array}$ & $\begin{array}{c}17.47 \\
(24.70)\end{array}$ & $\begin{array}{c}19.40 \\
(26.09)\end{array}$ & $\begin{array}{c}21.37 \\
(27.53)\end{array}$ & $\begin{array}{c}23.47 \\
(28.97)\end{array}$ & $\begin{array}{c}20.45 \\
(26.94)\end{array}$ \\
\hline $\begin{array}{l}\text { HWT }\left(50^{\circ} \mathrm{C}\right)+\text { Dithane M- } \\
45(0.2 \%)+T . \text { harzianum } \\
(0.5 \%)\end{array}$ & $\begin{array}{c}12.23 \\
(20.46)\end{array}$ & $\begin{array}{c}13.40 \\
(21.46)\end{array}$ & $\begin{array}{c}15.63 \\
(23.28)\end{array}$ & $\begin{array}{c}19.17 \\
(25.96)\end{array}$ & $\begin{array}{r}15.16 \\
(23.07)\end{array}$ \\
\hline $\begin{array}{l}\text { Bavistin }(0.2 \%)+\text { HWT } \\
\left(50^{\circ} \mathrm{C}\right)+T . \text { harzianum } \\
(0.5 \%)\end{array}$ & $\begin{array}{c}7.2 \\
(15.62)\end{array}$ & $\begin{array}{c}10.37 \\
(18.77)\end{array}$ & $\begin{array}{c}13.13 \\
(21.24)\end{array}$ & $\begin{array}{c}15.37 \\
(23.07)\end{array}$ & $\begin{array}{c}11.46 \\
(19.33)\end{array}$ \\
\hline $\begin{array}{l}\text { Neemazal }(0.4 \%)+\text { Antacol } \\
(0.3 \%)+\text { HWT }\left(50^{\circ} \mathrm{C}\right)\end{array}$ & $\begin{array}{c}18.37 \\
(25.37)\end{array}$ & $\begin{array}{c}21.37 \\
(27.53)\end{array}$ & $\begin{array}{c}24.30 \\
(29.55)\end{array}$ & $\begin{array}{c}27.40 \\
(31.56)\end{array}$ & $\begin{array}{c}22.78 \\
(28.31)\end{array}$ \\
\hline $\begin{array}{l}\text { Antracol }(0.3 \%)+\text { Cow } \\
\text { urine }(5 \%)+T . \text { viride } \\
(0.5 \%)\end{array}$ & $\begin{array}{c}17.23 \\
(24.52)\end{array}$ & $\begin{array}{c}20.47 \\
(26.89)\end{array}$ & $\begin{array}{c}23.43 \\
(28.95)\end{array}$ & $\begin{array}{c}24.33 \\
(29.55)\end{array}$ & $\begin{array}{c}21.17 \\
(26.82)\end{array}$ \\
\hline Control & $\begin{array}{c}39.30 \\
(38.82)\end{array}$ & $\begin{array}{c}43.33 \\
(41.17)\end{array}$ & $\begin{array}{c}57.63 \\
(49.39)\end{array}$ & $\begin{array}{c}64.10 \\
(53.20)\end{array}$ & $\begin{array}{c}50.00 \\
(45.40)\end{array}$ \\
\hline Mean & $\begin{array}{c}18.64 \\
(24.92)\end{array}$ & $\begin{array}{c}21.39 \\
(26.99)\end{array}$ & $\begin{array}{c}25.92 \\
(29.99)\end{array}$ & $\begin{array}{c}28.97 \\
(32.05)\end{array}$ & $\begin{array}{c}23.46 \\
(28.35)\end{array}$ \\
\hline
\end{tabular}


Table.5 Effect of integration of different rhizome treatments on rhizome recovery and other parameters of seed ginger during 2014-15

\begin{tabular}{|c|c|c|c|c|c|c|}
\hline \multirow[b]{2}{*}{ Treatments } & \multirow{2}{*}{$\begin{array}{c}\text { Rhizome } \\
\text { recovery } \\
(\%)\end{array}$} & \multicolumn{5}{|c|}{ Rhizome health parameters } \\
\hline & & $\begin{array}{l}\text { Bud length } \\
\text { (mm) }\end{array}$ & Mould & Shriveling & Bud colour & Sprouting \\
\hline $\begin{array}{l}\text { Neemazal }(0.4 \%)+\text { Antacol } \\
(0.3 \%)+\text { HWT }\left(50^{\circ} \mathrm{C}\right)\end{array}$ & $\begin{array}{c}75.53 \\
(62.40)\end{array}$ & 3.3 & - & - & Creemish to White & ++ \\
\hline $\begin{array}{l}\text { HWT }\left(50^{0} \mathrm{C}\right)+\text { Dithane M- } \\
45(0.2 \%)+T . \text { harzianum } \\
(0.5 \%)\end{array}$ & $\begin{array}{c}84.27 \\
(66.64)\end{array}$ & 3 & - & - & Creemish to White & ++ \\
\hline $\begin{array}{l}\text { Bavistin }(0.2 \%)+\mathrm{HWT} \\
\left(50^{\circ} \mathrm{C}\right)+T . \text { harzianum } \\
(0.5 \%)\end{array}$ & $\begin{array}{c}86.53 \\
(68.49)\end{array}$ & 2.3 & - & - & Creemish to White & ++ \\
\hline $\begin{array}{l}\text { Neemazal }(0.4 \%)+ \\
\text { Antacol }(0.3 \%)+\text { HWT } \\
\left(50^{\circ} \mathrm{C}\right)\end{array}$ & $\begin{array}{c}76.53 \\
(61.03)\end{array}$ & 3.3 & - & - & Creemish to White & ++ \\
\hline $\begin{array}{l}\text { Bavistin }(0.2 \%)+T \\
\text { harzianum }(0.5 \%)+\text { Cow } \\
\text { urine }(5 \%)\end{array}$ & $\begin{array}{c}80.43 \\
(63.75)\end{array}$ & 2.3 & - & - & Creemish to White & ++ \\
\hline Control & $\begin{array}{c}38.47 \\
(38.33)\end{array}$ & 5.3 & ++ & ++ & Brown to Black & + \\
\hline Mean & $\begin{array}{c}74.13 \\
(60.11)\end{array}$ & & & & & \\
\hline $\mathrm{CD}_{(0.05)}$ & & 0.17 & & & & \\
\hline
\end{tabular}

Fig.1 Frequency distribution of different fungi associated with storage rot of ginger

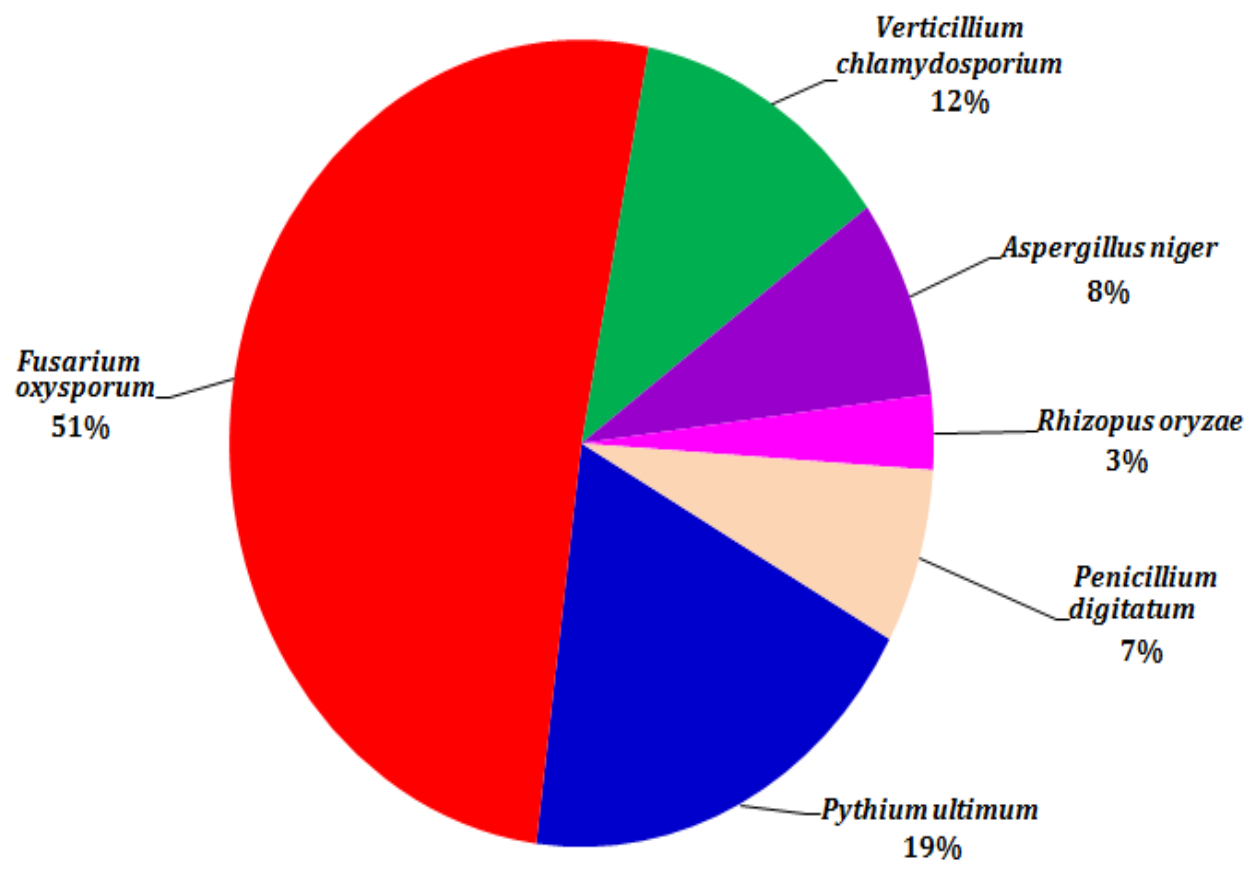


Fig.2 Phylogenetic tree showed the relationship among fungal isolated causing ginger rot, ITS gene sequences with reference sequences obtained through BLAST analysis. The sequence alignment was performed using the CLUSTAL W program and trees were constructed using maximum likelihood method with algorithm using MEGA4 software (Tamura et al., 2007). One thousand bootstrap replicates were performed. Bootstrap values are indicated on the branches

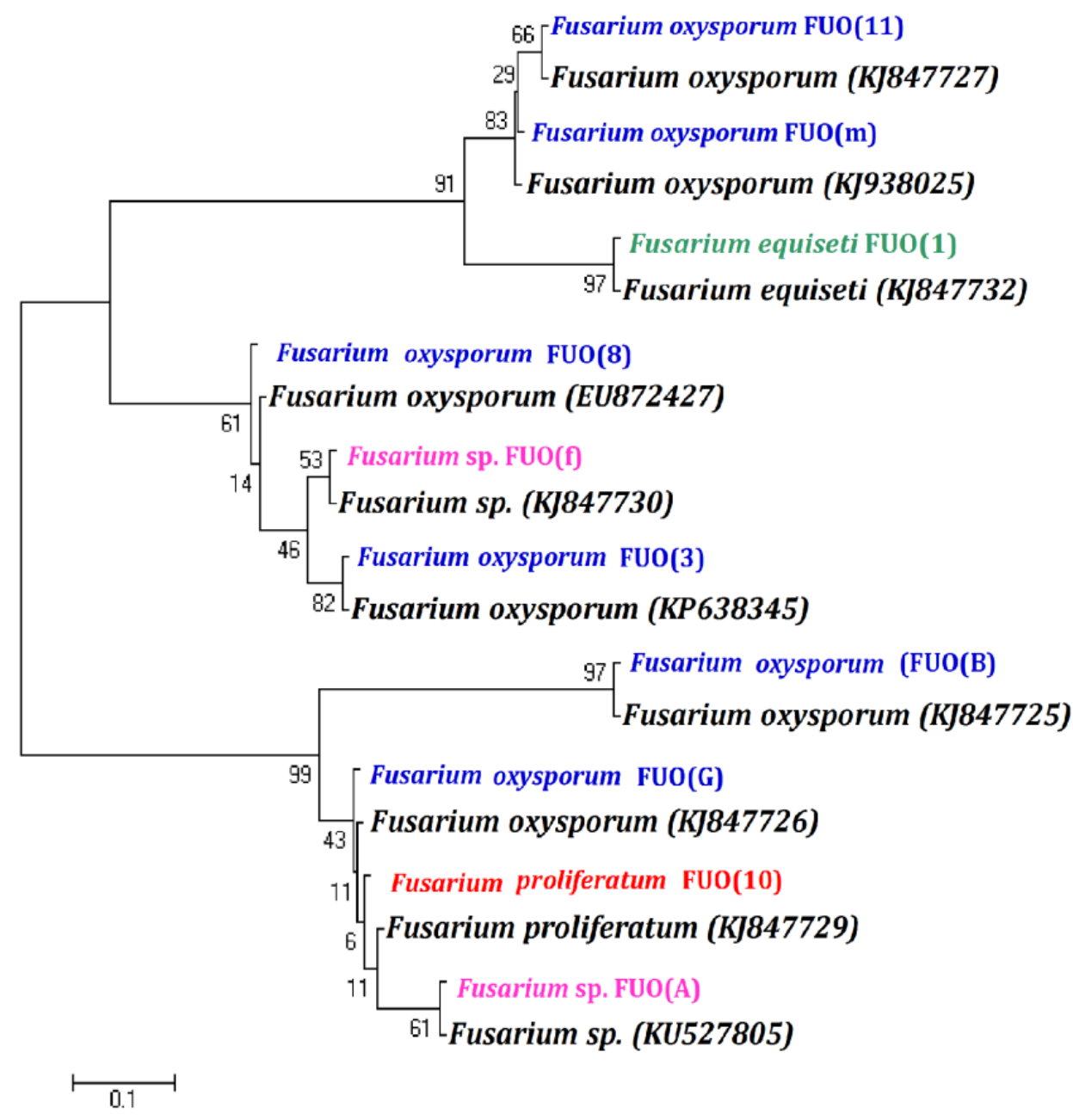

The maximum disease incidence $(41.57 \%)$ was however, found at 0 hour of curing. It was inferred from the data that the curing for 36 to 40 hours decreased disease incidence and increased rhizome recovery. The curing of rhizomes offered effective means of reducing post-harvest decay by way of water loss during the process of curing. Besides, it also strengthened the skin of rhizomes. The curing also involved suberization of outer tissues of rhizomes followed by the development of wound periderm which acted as an effective barrier against infection and water loss (Proctor 1985). Field experiment was carried out in a Randomized Block Design under storage conditions in pits during 2014-15 in the first week of December at vegetable farm of the University. All the treatments significantly reduced the storage rot incidence over control. The data were recorded at 30, 60, 90 and 120 days interval. The data indicate that minimum incidence 
was recorded in treatments, Carbendazim + HWT + T. harzianum (7.2\%) and HWT + Mancozeb $+T$. harzianum $(12.23 \%)$ after 30 days of storage as compared to control where incidence was $39.30 \%$ (Table 5). Thus both the treatments Carbendazim $+\mathrm{HWT}+T$. harzianum and HWT + Mancozeb $+T$. harzianum were statistically different from each other. Minimum storage rot incidence was also recorded in treatments Carbendazim + HWT + T. harzianum $(15.37 \%)$ and HWT + Mancozeb $+T$. harzianum (19.17\%), after 120 days of storage. Incidence of rot was maximum $(64.10 \%)$ in control rhizomes after 120 days of storage. The interaction between treatment, storage interval and between the years was found to be significant. From the perusal of data it is evident that highest rhizome recovery $(86.53 \%)$ was obtained in treatment Bavistin + HWT $+T$. harzianum during 2015 (Table 4).

The data further revealed that minimum rhizome recovery $(38.47 \%)$ was obtained in a control treatment and all the treatments were statistically significant among each other (Table 5). It is obvious from the visual observations that there was presence of mould in the control treatment while no mould was observed in other treatments.

The data indicated that no surface shriveling was observed in all the treatments while it was moderate $(30-70 \%)$ in control treatment. Similarly, moderate surface sprouting (30$70 \%$ ) was observed in all the treatments except control treatment where slight $(<30 \%)$ surface sprouting was observed. Creemish to white bud colour was observed in all the treatments except control where bud colour was brown to black.

Though no information is available in literature on the combined effect of different combinations of fungicides, botanicals and biocontrol in management of storage rot of ginger, yet soil application and amendments of $T$. harzianum, $T$. viride, neem cake and their combination have also been reported effective for the management of Fusarium wilt of gladiolus (Kavitha et al., 2013).

Chandel and Sharma (2014), used botanicals, biofumigants and antagonists application in managing stem rot disease caused by Rhizoctonia solani Kuhn in carnation. Studies on the effect of pre-storage treatments on storage rot of ginger revealed that the prestorage treatment with Topsin-M and Bavistin each at $0.2 \%$ concentration for $60 \mathrm{~min}$ reduced incidence of storage rot, loss in rhizome weight, surface shriveling, sprouting of ginger and increased the recovery of the rhizomes (Dohroo, 2012).

Ramteke and Kamble (2011), studied the effect of carbon and nitrogen sources, temperature, $\mathrm{pH}$ levels and light spectra on mycelial growth of benomyl sensitive and resistant isolates of Fusarium solani. Singh et al., (2007) reported that treatment of tomato seeds with combination of Trichoderma harzianum and Carbendazim resulted in highest disease control (84\%) of $R$. solani at 60 days.

Tripathi et al., (2008) used some essential oils as post-harvest botanical fungicides in the management of grey mould of grapes caused by Botrytris cinerea. Ristaino and Papavizas (2010) used two fungal antagonists viz., T. viride and $T$. harzianum along with fungicide Carbendazim as seed treatment and soil drench results in significant inhibition in growth of Rhizoctonia solani in cabbage. Dohroo et al., (2012) reported that the effect of soil application of $T$. harzianum bioformulation and rhizome seed treatment with onion and garlic were most potent in limiting the soft rot of ginger. Ojaghian et al., (2014) conducted in vitro and in vivo experiments to evaluate antifungal activity of 
crude extracts derived from neem and ginger rhizomes against carrot caused by Sclerotinia sclerotiorum. Gupta et al., (2016), deciphered gentisyl alcohol from Phoma herbarum endophytic in Curcuma Longa L. and its antagonistic activity towards leaf spot pathogen Colletotrichum gloeosporioides. B. Devi and Thakur (2016) used bioagents, botanicals and fungicides under both in vitro and in vivo conditions against blanded leaf and sheath blight of maize. Rahman et al., (2016), evaluated different plant extract as selective Pesticides for Integrated Pest Management of different plants. M. I. Devi and Devi (2017), described combination of fungicides, botanicals and bioagents under in vitro and in vivo conditions to manage the Grey leaf spot of mango.

In conclusion, the frequency occurrence of Fusarium was most dominant in ginger rots. Among various diseases storage rot is a serious menace of ginger Zingiber officinale due to its worldwide occurrence. Storage rot of ginger caused by Fusarium oxysporum $\mathrm{f}$. sp. zingiberi in storage is one of the major problems for successful ginger cultivation. Seven fungi were isolated from diseased rhizomes and frequency occurrence of Fusarium oxysporum was maximum (50\%) among fungi causing storage rot of ginger in storage pits and heaps. Disease management practice alone is not sufficient until integrated with other components, as disease is a complex phenomenon governed by many factors. The integration of effective fungicides with plant oils, botanicals and antagonists were important for the successful management of plant diseases. Taking into consideration we use integrated disease management practice and results indicate that minimum incidence of disease was recorded when we used combination of treatments Bavistin + HWT $+T$. harzianum in a compatible manner.

\section{Acknowledgment}

We acknowledge the financial support provided by Dr. Yashwant Singh Parmar University of Horticulture and Forestry, Nauni, Solan, Himachal Pradesh, India for providing necessary facility to carry out this research work.

\section{Competing interests}

The authors declare no conflict of interest.

\section{References}

Basilico, M., and Basilico, J. 1999. Inhibitory effects of some spice essential oils on Aspergillus ochraceus NRRL 3174 growth and ochratoxin A production. Lett. Appl. Microbiol. 29(4): 238-241.

Brent, K. J., and Hollomon, D. W. (1995). Fungicide resistance in crop pathogens: How can it be managed? GIFAP Brussels.

Chandel, S., and Sharma, S. 2014. Botanicals, biofumigants and antagonists application in managing stem rot disease caused by Rhizoctonia solani Kuhn in carnation. J. Biopest. 7(1): 3-10

Devi, B., and Thakur, B. R. 2016. Integrated Management of Banded Leaf and Sheath Blight of Maize Caused by Rhizoctonia solani f. sp. sasakii. Proc. Nat. Acad. Sci. Biol. Sci. doi:10.1007/s40011-016-0814$\mathrm{z}$.

Devi, M. I., and Devi, R. K. T. 2017. Management of Grey leaf spot of mango with fungicides, botanicals and bioagents in vitro and in vivo condition in Manipur. J. Mycopathol. Res. 54(4): 527-530.

Dohroo, N. 1993. ICAR report on multi location project on rhizome rot of ginger. Dr YS Parmar University of Horticulture and Forestry, Nauni-solan, 4(4): 38.

Dohroo, N. 1995. Integrated management of yellows of ginger. Indian Phytopathol. 48(1): 90-92.

Dohroo, N. 2012. Etiology and management of storage rot of ginger in Himachal Pradesh. Indian Phytopathol. 54: 49-54. 
Dohroo, N., Kansal, S., Mehta, P., and Ahluwalia, N. 2012. Evaluation of ecofriendly disease management practices against soft rot of ginger caused by Pythium aphanidermatum. Plant Dis. Res. 27(1): 1-5.

Ernst, E., and Pittler, M. 2000. Efficacy of ginger for nausea and vomiting: a systematic review of randomized clinical trials. British J. Anaesth. 84(3): 367-371.

Grzanna, R., Lindmark, L., and Frondoza, C. G. 2005. Ginger - an herbal medicinal product with broad anti-inflammatory actions. J. Med. Food. 8(2): 125-132.

Gupta, S., Kaul, S., Singh, B., Vishwakarma, R. A., and Dhar, M. K. 2016. Production of Gentisyl Alcohol from Phoma herbarum Endophytic in Curcuma longa L. and Its Antagonistic Activity Towards Leaf Spot Pathogen Colletotrichum gloeosporioides. Appl. Biochem. Biotechnol. 180(6): 1093-1109.

Hsiang, C.-Y., Lo, H.-Y., Huang, H.-C., Li, C.C., Wu, S.-L., and Ho, T.-Y. 2013. Ginger extract and zingerone ameliorated trinitrobenzene sulphonic acid-induced colitis in mice via modulation of nuclear factor- $\kappa \mathrm{B}$ activity and interleukin-1 $\beta$ signalling pathway. Food Chem. 136(1): 170-177.

Kavitha, T., Ravichandra, N., and Sunitha, T. 2013. Management of root knot nematode, Meloidogyne incognita infecting carnation in commercial polyhouse. Adv. Life Sci. 2 (1): 29-30.

Kim, E.-C., Min, J.-K., Kim, T.-Y., Lee, S.-J., Yang, H.-O., Han, S., Kim, Y.-M., and Kwon, Y.-G. 2005. [6]-Gingerol, a pungent ingredient of ginger, inhibits angiogenesis in vitro and in vivo. Biochem. Biophys. Res. Comm. 335(2): 300-308.

Mitra, M., and Subramaniam, L. S. 1928. Fruitrot disease of cultivated cucurbitaceae caused by Pythium Aphanidermatum: (Eds.) Fitz: Government of India Central Publication Branch.

Ojaghian, M. R., Wang, L., qi Cui, Z., Yang, C., Zhongyun, T., and Xie, G.-L. 2014.
Antifungal and SAR potential of crude extracts derived from neem and ginger against storage carrot rot caused by Sclerotinia sclerotiorum. Ind. Crops Prod. 55: 130-139.

Proctor, F. J. 1985. Harvesting, post-harvest handling and storage for better quality horticultural produce. In: XII African Symposium on Horticultural Crops pp. 359-368.

Rahman, S., Biswas, S. K., Barman, N. C., and Ferdous, T. 2016. Plant extract as selective pesticide for integrated pest management. Biotechnol. Res. 2 (1): 610.

Rahmani, A. H. 2014. Active ingredients of ginger as potential candidates in the prevention and treatment of diseases via modulation of biological activities. Int. J. Physiol. Pathophysiol. Pharmacol. 6(2): 125.

Ram, L., and Thakur, T. L. 2010. Association of different fungi under traditional storage of ginger rhizomes. J. Plant Pathol. 3: 678679.

Ramteke, P., and Kamble, S. 2011. Physiological studies in Fusarium solani causing rhizome rot of ginger (Zingiber officinale Rosc.). The Bioscan. 6(2): 195197.

Ravindran, P., and Babu, K. N. 2005. Ginger: The Genus Zingiber. Medicinal and Aromatic Plants-Industrial Profiles: CRC Press.

Rawlins, T. E. 1933. Phytopathological and botanical research methods.

Ristaino, J. E. B., and Papavizas, G. C. 2010. Biological control of Rhizoctonia stem canker and black scurf of potato. Phytopathology. 75: 560-564.

Sharma, N., and Jain, A. 1977. Final report submitted to Indian Council of Agricultural Research on ginger diseases and its control.

Shukla, Y., and Singh, M. 2007. Cancer preventive properties of ginger: a brief review. Food Chem. Toxicol. 45(5): 683690. 
Singh, C. B., Shipra, S., Preeti, J., and Yadav, F. D. 2007. Eco-friendly management of vascular wilt of solanaceous vegetables. Flora Fauna Jhansi, 13: 98-100.

Suman, A., Verma, P., Yadav, A. N., Srinivasamurthy, R., Singh, A., Prasanna, R. 2016. Development of hydrogel based bio-inoculant formulations and their impact on plant biometric parameters of wheat (Triticum aestivum L.). Int. J. Curr. Microbiol. Appl. Sci. 5:890-901.

Tripathi, P., Dubey, N., and Shukla, A. 2008. Use of some essential oils as post-harvest botanical fungicides in the management of grey mould of grapes caused by Botrytis cinerea. World J. Microbiol. Biotechnol. 24 (1): 39-46.

Verma, P., Yadav, A. N., Kazy, S. K., Saxena, A. K., Suman, A. 2014. Evaluating the diversity and phylogeny of plant growth promoting bacteria associated with wheat (Triticum aestivum) growing in central zone of India. Int. J. Curr. Microbiol. Appl. Sci. 3:432-447.

Verma, P., Yadav, A. N., Khannam, K. S., Kumar, S., Saxena, A. K., and Suman, A. 2016a. Molecular diversity and multifarious plant growth promoting attributes of Bacilli associated with wheat (Triticum aestivum L.) rhizosphere from six diverse agro-ecological zones of India. J. Basic Microbiol. 56 (1): 44-58.

Verma, P., Yadav, A. N., Khannam, K. S., Mishra, S., Kumar, S., Saxena, A. K., Suman, A. 2016b. Appraisal of diversity and functional attributes of thermotolerant wheat associated bacteria from the peninsular zone of India. Saudi J. Biol. Sci. doi:10.1016/j.sjbs.2016.01.042.

Verma, P., Yadav, A. N., Khannam, K. S., Panjiar, N., Kumar, S., Saxena, A. K., Suman, A. 2015a. Assessment of genetic diversity and plant growth promoting attributes of psychrotolerant bacteria allied with wheat (Triticum aestivum) from the northern hills zone of India. Ann. Microbiol. 65:1885-1899.

Verma, P., Yadav, A. N., Kumar, V., Khan, Md. A., Saxena, A. K. 2017. Microbes in termite management: Potential role and strategies. In: Sustainable Termite Management. Springer, https://doi.org/10. 1007/978-3-319-68726-1_9

Verma, P., Yadav, A. N., Shukla, L., Saxena, A. K., Suman, A. 2015b. Alleviation of cold stress in wheat seedlings by Bacillus amyloliquefaciens IARI-HHS2-30, an endophytic psychrotolerant K-solubilizing bacterium from NW Indian Himalayas. Natl. J. Life Sci. 12:105-110.

Yadav, A. N., Sachan, S. G., Verma, P., and Saxena, A. K. 2016b. Bioprospecting of plant growth promoting psychrotrophic Bacilli from cold desert of north western Indian Himalayas. Indian J. Exp. Biol. 54 (2): 142-150.

Yadav, A. N., Sachan, S. G., Verma, P., Kaushik, R., and Saxena, A. K. 2016a. Cold active hydrolytic enzymes production by psychrotrophic Bacilli isolated from three sub-glacial lakes of NW Indian Himalayas. J. Basic Microbiol. 56: 294-307.

Yadav, A. N., Verma, P., Kumar, V., Sangwan, P., Mishra, S., Neha, P., Gupta, V. K., and Saxena, A. K. 2017. Biodiversity of the Genus Penicillium in Different Habitats. In: Gupta VK, Rodriguez-Couto S (eds) New and Future Developments in Microbial Biotechnology and Bioengineering, Penicillum System Properties and Applications. Elsevier. Pp. 3-18. doi:10.1016/B978-0-444-635013.00001-6.

\section{How to cite this article:}

Sushma Sharma, Netra Prakash Dohroo, Shanmugam Veerubommu, Sumitra Phurailatpam, Neelam Thakur and Ajar Nath Yadav. 2017. Integrated Disease Management of Storage Rot of Ginger (Zingiber officinale) caused by Fusarium sp. in Himachal Pradesh, India. Int.J.Curr.Microbiol.App.Sci. 6(12): 3580-3592. doi: https://doi.org/10.20546/ijcmas.2017.612.415 